\title{
DIMENSI KEMANUSIAAN DALAM SISTEM EKONOMI ISLAM (Sebuah Kajian dengan Pendekatan Filsafat Hukum Islam)
}

\author{
Maskur Rosyid $^{1}$
}

\begin{abstract}
Abstrak
Islam telah menyediakan suatu sistem ekonomi yang meniscayakan penggunaan sumber-sumber daya yang diberikan Allah untuk memenuhi kebutuhankebutuhan pokok umat manusia dan memberikan kepada mereka kondisi kehidupan yang baik. Lebih dari itu, sistem ekonomi Islam bukan hanya berlandaskan kepada nilai-nilai Ketuhanan dan moral, tetapi juga berdasarkan kepada prinsip kemanusiaan. Hal inilah yang menjadi antithesis dari sistem kapitalis yang selama ini telah dipaktikkan yang mendorong manusia menjadi pelaku ekonomi yang hedonistik, sekularistik, dan materialistik. Melalui pola filsafat hukum Islam permasalahan akan dianalisis dengan cara berpikir secara menyeluruh, mendasar (radikal), dan reflektis-kritis.

Kata kunci; Dimensi Kemanusiaan, Kemanusiaan, System Ekonomi Islam, Sistem Ekonomi Kapitalis
\end{abstract}

Islam has provided an economical system which certainly reflects the utilization of resources given by Allah to fulfill human's principal needs and give them good life. Moreover, Islamic economical system is not only based on divinity and moral values, but also based on humanism principal. This becomes the antithesis of the capitalism system which had been practiced all these times which forced human to be a hedonistic, secularist, and materialistic economy doer. Through the pattern of Islamic philosophical law, the problems will be analyzed by thinking comprehensively, radically, and reflectivecritically.

Key word: Humanism Dimension, Humanism, Islamic Economical System, Capitalist Economical System

\section{Pendahuluan}

Sistem ekonomi kapitalis yang telah diberlakukan selama ini memunculkan suatu pandangan yang menempatkan aspek material yang bebas dari dimensi nilai pada posisi yang dominan. Pandangan hidup yang berpijak pada ideologi

1 Penulis adalah dosen tetap pada Sekolah Tinggi Ekonomi Syariah Islamic Village Kelapa Dua Tangerang 
materialisme ini pada akhirnya mendorong manusia menjadi pelaku ekonomi yang hedonistik, sekularistik, dan materialistik. Dampaknya adalah terjadinya malapetaka dan bencana dalam kehidupan sosial masyarakat seperti eksploitasi, disparitas kekayaan antar golongan dalam masyarakat atau antar negara di dunia, dan yang lebih tragis lagi adalah lunturnya sikap kebersamaan dan persaudaraan serta timbulnya penyakit-penyakit sosial.

Berdasarkan fakta tersebut, banyak pemerhati ekonomi yang berpendapat bahwa sistem ekonomi kapitalis telah gagal menyelesaikan persoalan kemanusiaan dan sosial ekonomi. Memang sistem ekonomi kapitalis mampu menyejahterakan individu atau negara tertentu secara materi, namun perlu diingat, bahwa kesejahteraan dan kemakmuran tersebut dibangun di atas penderitaan orang atau negara lain. Kapitalis tidak mampu menyelesaikan ketimpangan dan kesenjangan sosial ekonomi bahkan sebaliknya ia menciptakan dan melanggengkan kesenjangan tersebut untuk mempertahankan eksistensinya (Iswadi, 2007: 48)

Dalam persoalan tersebutlah Islam melontarkan kritik terhadap sistem ekonomi kapitalis yang dianggap bertanggung jawab terhadap perubahan arah, pola, dan struktur perekonomian dunia sekarang ini. Perlu ada suatu kajian yang intensif dalam memberikan alternatif pandangan, rumusan, dan strategi pembangunan ekonomi yang lebih humanistik dengan menggali inspirasi nilainilai yang terkandung dalam sumber-sumber Islam.

Namun, tulisan ini tidak bermaksud untuk menjawab permasalahan itu semua, melainkan hanya sedikit ingin menelusuri dimensi kemanusiaan yang terdapat dalam sistem ekonomi Islam yang membedakannya dengan sistemsistem ekonomi lainnya. Pembahasannya merupakan ranah filsafat hukum Islam, dengan kata lain, permasalahan akan dianalisis dengan cara berpikir secara menyeluruh, mendasar (radikal), dan reflektis-kritis.

\section{Sekilas Tentang Ekonomi Islam}

Secara umum, ekonomi dalam Islam dapat didefinisikan sebagai ilmu yang mempelajari segala prilaku manusia dalam memenuhi kebutuhan hidupnya dengan tujuan memperoleh kedamaian dan kesejahteraan dunia-akhirat. Kata Islam setelah Ekonomi dalam ungkapan Ekonomi Islam berfungsi sebagai identitas tanpa memengaruhi makna atau definisi ekonomi itu sendiri. Karena definisinya lebih ditentukan oleh perspektif atau lebih tepat lagi worldview yang digunakan sebagai landasan nilai. Untuk itu, perlu diuraikan secara singkat definisi ekonomi Islam menurut beberapa pemikir:

1. Pengetahuan dan aplikasi ajaran-ajaran dan aturan-aturan syariah yang mencegah ketidakadilan dalam pencarian dan pengeluaran sumbersumber daya, guna memberikan kepuasan bagi manusia dan memungkinkan mereka melaksanakan kewajiban-kewajiban mereka terhadap Allah dan masyarakat (Hasanuzzaman). 
2. Respon "para pemikir muslim terhadap tantangan-tantangan ekonomi zaman mereka. Dalam upaya ini mereka dibantu oleh Alqur'an dan Sunnah maupun akal dan pengalaman (M.N. Siddiqi).

3. Ekonomi Islam merupakan representasi perilaku muslim dalam suatu masyarakat muslim tertentu (Syed Nawab Haider Naqvi).

4. Bertujuan mempelajari kesejahteraan manusia yang dicapai dengan mengorganisir sumber-sumber daya bumi atas dasar kerjasama dan partisipasi (M. Akram Khan).

5. Suatu ilmu pengetahuan sosial yang mempelajari permasalahan ekonomi dari orang-orang memiliki nilai-nilai Islam (M. A. Mannan).(lihat dalam Muhammad, 2004: 5-6)

Untuk mengetahui ekonomi dalam Islam, dapat dilakukan dengan menelusuri term-term dalam Alqur'an yang berkaitan dengan ekonomi. Ada beberapa terma dalam Alqur'an yang berkaitan dengan konsep ekonomi, diantaranya adalah term: al-tijarah, al-bay', tadayana, dan isytara .

Term tijarah berasal dari kata dasar tajara, tajran dan tija>ratan, yang bermakna berdagang atau berniaga. Dalam Alqur'an, term tijarah dengan berbagai macam bentuknya terulang sebanyak 9 kali ('Abd al-Bâqî, 1987: 152). Kata tijarah dalam Alqur'an memiliki dua pemahaman. Pertama, dipahami dengan perdagangan yaitu pada surat al-Baqarah (2): 282. Kedua, dipahami dengan perniagaan dalam pengertian umum. Jika dihubungkan dengan konteksnya masing-masing, maka pengertian perniagaan tidak hanya berhubungan dengan hal-hal yang bersifat material atau kuantitas, tetapi perniagaan juga ditujukan kepada hal yang bersifat immaterial kualitatif, seperti dala at-Taubah (9): 24 dan as-Saff (61); 10-11.

Ayat-ayat tersebut menjelaskan tentang petunjuk transaksi yang menguntungkan dan bermanfaat, sehingga pelakunya akan mendapatkan keuntungan besar dan keberhasilan yang kekal. Perniagaan dimaksud adalah tetap dalam keimanan, keikhlasan amal kepada Allah dan berjihad dengan jiwa dan harta dengan menyebarkan agama dan meninggikan kalimat-Nya (alMarâghî, 1993: 145-146). Dari pemahaman ini dapat diambil pemaknaan bahwa prilaku bisnis bukan semata-mata perbuatan dalam hubungan kemanusiaan semata tetapi mempunyai sifat Ilahiyah. Adanya sikap kerelaan diantara yang berkepentingan, dan dilakukan dengan keterbukaan merupakan ciriciri dan sifatsifat keharusan dalam bisnis. Jika ciri-ciri dan sifat-sifat di atas tidak ada, maka bisnis yang dilakukan tidak akan mendapat keuntungan dan manfaat. Ayat-ayat di atas jelas memperlihatkan hakikat bisnis yang bukan semata-mata material, tetapi juga immaterial.

Adapun term bai' dengan berbagai variasinya terulang dalam Alqur'an sebanyak 9 kali ('Abd al-Bâqî, 141). Term ini berarti menjual atau memberikan sesuatu yang berharga dan mengambil darinya suatu harga dan keuntungan. 
Term bai' dalam Alqur'an digunakan dalam dua pengertian. Pertama, dalam konteks bahwa tidak ada jual-beli di hari qiamat, karena itu Alqur'an menyeru agar membelanjakan, mendayagunakan dan mengembangkan harta benda berada dalam proses yang tidak bertentangan dengan keimanan dan bertujuan untuk mencari keuntungan yang dapat menjadi bekal pada hari kiamat (alBaqarah (2): 254). Kedua, Term bai' dalam pengertian jual beli yang halal, dan larangan untuk memperoleh atau mengembangkan harta benda dengan jalan riba (al-Baqarah (2): 275).

Alqur'an juga menggunakan term isytara. Kata isytara dengan berbagai ragamnya terulang sebanyak 25 kali ('Abd al-Bâqî, 381). Secara umum kata isytara dan berbagai ragamnya lebih banyak mengandung makna transaksi antara manusia dengan Allah atau transaksi sesama manusia yang dilakukan karena dan untuk Allah, atau juga transaksi dengan tujuan keuntungan manusia walaupun dengan menjual ayat-ayat Allah. ${ }^{2}$

Alqur'an juga menggunakan terma tadayana yang disebutkan hanya satu kali yaitu pada surat al-Baqarah (2): 282. Ayat ini digunakan dalam pengertian mu'amalah yakni jual-beli, utang piutang, sewa menyewa dan lain sebagainya yang jika dilakukan tidak secara tunai hendaknya pencatatan dengan benar.

Dari penjelasan di atas, terlihat jelas bahwa terma bisnis dalam al- Qur'an baik yang terambil dari term al-tijarah, al-bai', tadayana, dan ishtara pada hakikatnya tidak semata-mata bersifat material, tetapi juga immaterial. Untuk itu pelaku bisnis harus sealu menjaga profesionalisme terhadap sesama dan menjaga ketaatan terhadap Allah. Dalam konteks inilah Alqur'an menawarkan keuntungan dengan suatu bursa yang tidak pernah mengenal kerugian, yaitu tijarah lan tabur (Quraish Shihab, 1997: 5).

\section{Islam, Kemanusiaan, dan Ekonomi}

Kemanusiaan adalah salah satu nilai dasar yang dijadikan pedoman dalam kehidupan berbangsa, bernegara dan bermasyarakat. Prinsip kemanusiaan yang mengandung ciri-ciri: pertama, mengandung nilai keadilan yakni kemunusiaan yang berkeadilan dan kedua, mengandung nilai keberadaban, yakni kemanusiaan yang berkeadaban. Makna kemanusiaan kerap kali lebih jelas jika berhadapan dengan kasus-kasus yang bertentangan dengan perikemanusiaan (Dawam Rahardjo, 1999: 49-50).

Berbeda dengan pandangan humanisme yang menyatakan "manusia itu adalah ukuran dari segala hal", pusat dari arti penting (significance) dan wadah

2 Seperti dalam beberapa ayat berikut: dalam at-Taubah (2): 111 kata isytara digunakan dalam pengertian membeli dalam konteks Allah membeli diri dan harta orang-orang mukmin, al-Baqarah (2): 16 untuk membeli kehidupan dunia dengan kehidupan akhirat, al-Baqarah (2): 86 untuk menjual diri dengan kekafiran, al-Baqarah (2): 90 untuk membeli kesesataan dengan petunjuk, dan al-Baqarah (2): 175 untuk menukar iman dengan kekafiran, Ali 'Imran (3): 177,187 untuk menukar ayat Allah dengan harga yang sedikit. 
dari segala kebajikan, Islam menempatkan kemanusiaan sebagai sesuatu yang sekunder dari nilai tauhid. Ketuhanan yang dalam kehidupan sehari-hari diekspresikan sebagai kebenaran, keadilan dan keindahan. Tauhid adalah sumber dari prinsip kemanusiaan. Kemanusiaan adalah konsekuensi dari ketuhanan. Karena itu, Tuhanlah yang paling berhak menilai dan menempatkan manusia di antara semua makhluk-Nya. Atas dasar itu, maka sesungguhnya kehidupan manusia itu dimuliakan oleh Allah, karena salah satu prinsip ajaran kemanusiaan Islam adalah pemuliaan hidup (al-Isra' (17): 70).

Sebenarnya sumber daya alam yang dianugerahkan oleh Allah kepada manusia secara kuantitas dan kualitas telah serba mencukupi dan bahkan melimpah ruah, tidak hanya bagi manusia tetapi juga bagi makhluk-makhluk lainnya. Tetapi manajemen terhadap sumberdaya tersebut oleh suatu kesatuan sosial dan politik kerap kali justru menciptakan kelimpahan yang berlebihan di satu pihak, dan kelangkaan serta kekurangan di pihak lain, terjadi perbedaan yang mencolok ( $g a p$ ) antara orang kaya yang sedikit jumlahnya dengan orang miskin yang besar jumlahnya. Ilmu ekonomi diciptakan untuk mengatur pengembangan sumberdaya dan distribusinya untuk seluruh manusia, setidaktidaknya dalam kesatuan-kesatuan tertentu.

Selain pemuliaan hidup, prinsip ajaran kemanusiaan lainnya dalam Islam adalah persamaan kedudukan manusia di hadapan Allah. Namun dalam kenyataannya, telah terjadi kelas-kelas sosial dalam masyarakat, seperti diperlihatkan dalam sistem kasta. Marx mengatakan bahwa setiap masyarakat dalam tahap perkembangan masyarakat itu selalu terdiri dari dua kelas yang antagonis, yakni kelas yang menindas dan yang ditindas. Dalam sosiologiekonomi juga dikenal stratifikasi masyarakat berdasarkan tingkat pendapatan atau tingkat kemakmuran. Di tingkat nasional atau dunia terdapat pembagian masyarakat, paling tidak dalam tiga strategi, yaitu lapisan yang paling miskin dan papa (the desititute), lapisan miskin (the poor), lapisan tengah (the middle income group) dan lapisan kaya (the rich), bahkan sekarang ada pula lapisan yang teramat kaya (super rich) (Dawam Rahardjo, 53).

Kondisi tersebut bertentangan dengan prinsip persamaan kedudukan manusia, karena dengan tingkat kekayaan atau pendapatan yang berbeda secara mencolok itu persamaan kedudukan menjadi tiada. Ketiadaan persamaan itu merupakan akibat dari sistem perbudakan atau dominasi (ar-riqab) yang bersifat menindas. Meskipun demikian Islam juga mengajarkan kebebasan dan keterbukaan akses terhadap sumberdaya dalam mencari rezeki (Lihat misalnya dalam an-Najm (53): 39 dan al-Jumu'ah (62): 10).

Oleh karena itu, maka setiap orang dimotivasi untuk mengerjakan sesuatu guna memperoleh hasil atau prestasi. Sebagai konsekuensinya, akan terjadi persaingan antara individu dalam mengerjakan dan meraih sesuatu hasil kerja dan prestasi. Kebebasan tersebut, yang merupakan hak azasi manusia bisa menimbul-kan ketidaksamaan hasil. Timbulnya pelapisan masyarakat berdasarkan perbedaan tingkat pendapatan tak bisa dihindarkan. Dalam hal ini 
Islam dapat menerima perbedaan dalam perolehan rezki dan kekayaan. Namun Islam, atas dasar prinsip keadilan, yakni untuk menciptakan keseimbangan baru dalam masyarakat, menetapkan prinsip "pembersihan" harta benda, berupa zakat. Prinsip ini juga berakar dari paham kemanusiaan, yakni supaya kemanusiaan yang pincang akibat kemiskinan dapat dipulihkan kembali (Adiwarman Azwar Karim, 2001: 34). Dengan demikian, maka prinsip kebebasan dan keadilan, juga merupakan bagian ketiga dan keempat dari kemanusiaan yang utuh.

Prinsip kemanusiaan yang kelima adalah kesatuan umat manusia. Prinsip kesatuan ini perlu dikemukakan, karena umat manusia saat ini dalam kenyataannya telah terbagi ke dalam suku-suku dan bangsa-bangsa. Selain itu manusia merupakan elemen hidup dan tidak dapat dikesampingkan dari sebuah sistem ekonomi.

Oleh karena itu, yang diperlukan adalah peningkatan moral individu yang mengubah keseluruhan pandangan manusia tentang kehidupan dan memotivasinya untuk bertindak secara benar berdasarkan nilai-nilai kemanusiaan. Ia harus menyediakan suatu sistem ekonomi yang manusiawi dan adil sehingga merestorasi martabat manusia (M. Umer Chapra, 2000: xxv). Akan tetapi, suatu pertumbuhan ekonomi yang realistis bisa jadi tidak membantu mengurangi angka pengangguran kecuali jika terdapat gerakan serentak menuju kepada teknologi yang kondusif bagi terciptanya kesempatan kerja penuh, atau seperti yang dikatakan oleh Schumacher, "suatu teknologi dengan wajah manusia" (F. Schumacher, 1973: 18). Barangkali hal ini menuntut penerapan dimensi manusia dalam semua bidang garap ekonomi yaitu produksi, konsumsi, distribusi dan sirkulasi. Dalam kerangka itulah, tulisan ini mencoba mengidentifikasi penerapan prinsip-prinsip kemanusiaan dalam suatu sistem ekonomi Islam kaitannya dengan aktivitas di bidang produksi, konsumsi, distribusi dan sirkulasi.

\section{Sistem Ekonomi yang Bercirikan Kemanusiaan}

Sistem ekonomi Islam mempunyai ciri ketuhanan dan moral, selain itu juga berkarakter kemanusiaan. Mungkin sebagian orang beranggapan bahwa kemanusiaan bertolak belakang dengan ketuhanan sehingga keduanya tidak bisa digabungkan. Persepsi tersebut tidak benar, setidaknya mereka yang menduga seperti itu lupa bahwa ide kemanusiaan berasal dari Allah. Allahlah yang memuliakan manusia dan menjadikannya khalifah di bumi.

Tujuan ekonomi Islam adalah menciptakan kehidupan manusia yang aman dan sejahtera. Yang dimaksud manusia di sini ialah semua golongan manusia, baik sebagai individu atau sebagai anggota masyarakat. Jika sistem ekonomi Islam itu bersandarkan pada nash Alqur'an dan as-Sunnah yang berarti nash ketuhanan, maka manusia berperan sebagai yang diserukan dalam nash itu. Dalam ekonomi manusia adalah tujuan dan sarana. Manusia diwajibkan melaksanakan tugasnya terhadap Tuhannya, terhadap dirinya, keluarganya, umatnya dan seluruh umat manusia. Manusialah yang menjadi wakil Allah di bumi ini (al-Baqarah (2): 30, serta memakmurkannya (Hûd (11): 61). 
Dengan demikian, dalam ekonomi Islam, manusia dan faktor kemanusiaan merupakan unsur utama. Faktor kemanusiaan dalam ekonomi Islam terdapat dalam kumpulan etika yang terdapat di dalam Alqur'an dan hadis serta tertulis di dalam buku-buku klasik (turatb) yang mencakup etika, kebebasan, kemuliaan, keadilan, sikap moderat, dan persaudaraan. Islam juga menganjurkan kasih sayang sesama manusia terutama kaum lemah, anak yatim, fakir miskin, dan yang terputus dalam perjalanan (al-Isra' (17): 26 dan al-Baqarah (2): 83). Islam mengajarkan sikap bertenggang rasa kepada para janda, orang tua renta, dan orang yang tidak sanggup bekerja. Buah yang dipetik dari etika ini ialah diakuinya oleh Islam milik individu, dengan syarat barang itu diperoleh dengan jalan halal. Islam juga menjaga milik individu dengan segala undang-undang dan etika. Adalah hak manusia untuk menjaga hak milik dan hartanya dari siapa saja yang ingin merusak. ${ }^{3}$

Islam memandang bahwa yang terpenting bukanlah pemilikan benda, tetapi kerja itu sendiri. Doktrin Alqur'an yang membentuk motivasi yang tinggi dalam bekerja umat Islam antara lain tercermin dalam al-Mulk (67): 15, yang memberi kesimpulan, pertama, bahwa bumi ini semua milik Allah, tetapi dianugerahkan kepada manusia. Kalimat "milik Allah" sebenarnya dapat dipahami bahwa bumi, air dan kekayaan yang terkandung di dalamnya bukan milik perseorangan karena kekuasaannya, melainkan untuk semua orang. Kedua, ayat itu menimbulkan etos yang mendorong umat Islam untuk "mengembara ke seluruh bumi" mencari rizki Allah. Ini mendorong untuk dilakukannya perdagangan dalam sekala luas seperti perdagangan antar daerah bahkan negara.

Salah satu tanda lain tentang ciri kemanusiaan pada ekonomi Islam ialah penyediaan sarana yang baik untuk manusia. Sebagai tatanan ekonomi, Islam menganjurkan manusia bekerja dan berusaha. Bekerja dan berusaha yang dilakukan oleh manusia itu diletakkan Allah pada timbangan kebaikan mereka. Tidak aneh apabila seorang muslim yang menjunjung kehidupan yang baik ini akan mendapatkan ganjaran bila ia tekun bekerja. Dalam rangka menjunjung kehidupan, manusia telah dikaruniai berbagai kenikmatan untuk memenuhi kebutuhannya baik material maupun spiritual. ${ }^{4}$

3 Harta atau kekayaan meupakan salah satu dari lima kepentingan pokok (ad-daruriyyat alkhams) kehidupan manusia yang harus dijamin dan dipelihara atau dilindungi. Kelima kepentingan pokok itu meliputi perlindungan terhadap religuiusitas atau agama (bifz ad-din), perlindungan terhadap jiwa (bifz an-nafs), perlindungan terhadap akal (bifz al'aq), perlindungan terhadap keturunan atau kehormatan (bifz an-nash), dan perlindungan terhadap harta (bifzan-mal). penjelasan mengenai hal ini lihat antara lain: Abu Hamid al-Ghazali, al-Mustasfa fi Tlm al-Usul (Beirut: Dar al-Kutub al-'Tlmiyyah, 1983), I: 174 dan Abu Ishaq Ibrahim bin Muhammad asy-Syatibi, al-Muwafaqat fi Usul as-Syari'ah (Beirut: Dar Ibn 'Affan, 1997), II: 24-25.

4 Islam memandang bahwa berusaha dan bekerja adalah bagian integral dari ajaran Islam. Terdapat sejumlah ayat al-Qur'an dan hadis Nabi yang menyerukan pentingnya aktivitas usaha, diantaranya: Allah berfirman "Apabila telah ditunaikan shalat, maka 
Tentu anjuran berusaha dan bekerja tersebut dalam konteks ajaran Islam bukan untuk semata-mata memperkaya diri sendiri. Karena Islam mengajarkan bahwa harta dan kekayaan mempunyai fungsi sosial. Secara tegas Alqur'an melarang perbuatan menumpuk harta dengan maksud untuk menimbun (alHumazah (104): 2), melarang mencari kekayaan dengan jalan tidak benar (alBaqarah (2): 188), dan memerintahkan membelanjakan secara baik (al-Baqarah (2): 261).

\section{Dimensi Kemanusiaan dalam Beberapa Aspek Ekonomi}

\section{Dimensi Kemanusiaan Dalam Bidang Produksi}

Sebagian penulis teori ekonomi Islam berpendapat bahwa ekonomi Islam hanya memfokuskan perhatiannya pada distribusi harta, dan tidak mementingkan masalah produksi. Dengan ungkapan lain, ekonomi Islam hanya memerhatikan distribusi harta secara adil dan merata, namun sama sekali tidak berhubungan dengan produksi. Ungkapan itu tidak sepenuhnya benar. Jika yang dimaksud dengan "produksi" adalah sarana, prasarana, dan cara kerja secara umum, maka ungkapan itu dapat diterima. Namun, jika yang dimaksud dengan produksi adalah tujuan, etika, dan peraturan yang berhubungan dengan produksi, maka ungkapan tersebut sulit untuk diterima.

Para ahli ekonomi menetapkan bahwa produksi terjadi melalui peranan tiga atau empat unsur yang saling berkaitan yaitu alam, modal, dan bekerja. Sebagian ahli ada yang menambahkan unsur disiplin. Para ekonomi muslim berbeda pendapat tentang apa yang ditetapkan Islam dari unsur-unsur ini. Sebagian dari mereka menghapuskan salah satu dari empat unsur itu berdasarkan teori, pertimbangan dan hasil penelitian mereka. Menurut Qardawi, jauh dari pembagian yang dilakukan oleh para ekonom kapitalis, pembagian di atas berperan dalam proses produksi tetapi unsur yang terutama adalah alam dan bekerja.Yang dimaksud dengan alam adalah segala kekayaan alam yang diciptakan Allah agar bisa dimanfaatkan oleh manusia sebagai bekal yang mereka butuhkan. Yang dimaksud dengan bekerja adalah segala usaha maksimal yang dilakukan manusia, baik lewat gerak anggota tubuh ataupun akal untuk menambah kekayaan, baik dilakukan secara perseorangan ataupun secara kolektif, baik untuk pribadi ataupun untuk orang lain (dengan menerima gaji) (Yusuf Qardhawi, 1997: 104).

bertebaranlah di muka bumi dan carilah karunia Allah" (al-Jumu'ah [62]: 10). Selain dalam ayat tersebut, seruan untuk bekerja juga dapat ditemukan dalam hadis Nabi "Sungguh seandainya salah seorang di antara kalian mengambil beberapa utas tali, kemudian pergi ke gunung kemudian kembali memikul seikat kayu bakar dan menjualnya, kemudian dengan hasil itu Allah mencukupkan kebutuhan hidupmu, itu lebih baik daripada meminta-minta kepada sesama manusia, baik mereka memberi maupun tidak". Lihat, Abu Abdillah Muhammad bin Isma'il bin Ibrahim bin Mugirah bin Bardizbah al-Bukhari, Shabih Bukhari, Kitab az-Zakah, Bab al-Isti'faf 'An alMas'alah, cet. ke-3 (Beirut: Dar Ibn Kasir, 1987), II: 535. 
Produktifitas timbul dari gabungan kerja antara manusia dan kekayaan alam. Adapun unsur lainnya, seperti disiplin, tidak lebih daripada strategi dan pengawasan, sementara modal tidak lebih daripada aset, baik berbentuk alat ataupun bangunan yang semuanya merupakan hasil kerja manusia. Ringkasnya, modal adalah pekerjaan yang terpendam. Jadi, sendi terpenting dan rukun yang terutama dalam produksi adalah bekerja. Bekerja dalam mengolah bumi hingga menghasilkan harta dan apa-apa yang baik.

Pada unsur pemanfaatan sumber daya alam oleh manusia dan aktivitas kerja yang dilakukan oleh manusia sehingga terbentuk produktivitas inilah, dimensi kemanusiaan dapat dikembangkan. Allah menjamin rezeki seluruh makhluk hidup yang merangkak di atas bumi, dan sudah menjadi Sunnatullah bahwa jaminan rezeki itu tidak akan mungkin di dapat kecuali dengan berusaha dan bekerja (al-Mulk (67): 15). Oleh sebab itu, Islam menganjurkan umatnya untuk memproduksi dan berperan dalam berbagai bentuk aktivitas ekonomi. Pada dasarnya, pekerjaan duniawi tidak hanya bermanfaat bagi individu pelakunya, tetapi juga penting untuk mencapai kemaslahatan masyarakat secara umum. Tidak logis jika dalam kehidupan di dunia ini manusia selalu mengambil tanpa pernah memberi apa pun kepada orang lain atau masyarakat, baik pemberian itu berbentuk ilmu ataupun tenaga (Yusuf Qardhawi, 108).

\section{Dimensi Kemanusiaan Dalam Bidang Konsumsi}

Mayoritas ahli ekonomi memfokuskan perhatiannya pada produksi. Mereka berusaha sekuat tenaga meningkatkan produksi serta memperbaiki kualitas serta kuantitasnya. Namun, bertambahnya hasil produksi tidak cukup untuk menciptakan kehidupan yang aman dan sejahtera. Sebab, sangat mungkin produk ini digunakan untuk urusan yang tidak bermanfaat bagi manusia, merusak jiwa dan akal, serta tidak membahagiakan keluarga dan masyarakat.

Memproduksi barang-barang yang baik dan memiliki harta adalah hak sah menurut Islam. Namun, pemilikan harta itu bukanlah tujuan tetapi sarana untuk menikmati karunia Allah dan jalan untuk mewujudkan kemaslahatan umum, yang memang tidak sempurna kecuali dengan harta yang dijadikan Allah bagi manusia sebagai dasar pijakan. Memiliki harta untuk disimpan, diperbanyak, lalu dihitung-hitung adalah tindakan yang dilarang. Itu merupakan penyimpangan terhadap petunjuk Tuhan dan memungkiri keberadaan istikblaf (al-Hadid (57): 7).

Harta benda yang diperoleh seseorang dari hasil usahanya tidak menimbulkan hak-hak istimewa kepadanya, sebaliknya manusia yang tidak memiliki harta bendapun tidak menjadi berkurang hak-hak kemanusiaannya dalam hidup masyarakat. Dengan demikian dimensi kemanusiaan dalam bidang konsumsi adalah bahwa manusia kaya karena kekayaan yang dimilikinya tidak mempunyai hak lebih atas manusia yang lain, sebaliknya manusia yang miskin karena kemiskinan yang dialaminya, tidak berkurang hak-hak kemanusiaannya dari manusia yang kaya. Keduanya mempunyai kedudukan yang sama. Atas 
dasar demikian, Islam mengajarkan agar orang kaya jangan merasa lebih dari orang miskin, tetapi harus menunjukkan sikap kasih sayang, peduli dan tetap menghargai kedudukannya sebagai manusia. Sebaliknya orang miskin tidak diperbolehkan merasa lebih kecil dari orang kaya, sehingga menimbulkan perasaan dengki dan iri (Ahmad Azhar Basyir, 1981: 9). Fenomena perbedaan perolehan hasil usaha menimbulkan kewajiban bagi manusia untuk membelanjakan harta. Ini merupakan pertanda jelasnya perintah membelanjakan harta, bukan sekedar anjuran yang boleh dikerjakan atau ditinggalkan. ${ }^{5}$

\section{Dimensi Kemanusiaan Dalam Bidang Distribusi}

Di antara bidang yang terpenting dalam perekonomian adalah bidang distribusi, sehingga sebagian penulis ekonomi Islam memusatkan perhatiannya kepada bidang ini. Islam menerapkan filsafat dan tatanan yang berbeda dari kedua sistem kapitalis dan sosialis. Islam memfokuskan perhatiannya pada distribusi sebelum membahas sektor produksi. Siapakah yang memilikinya? Dengan cara bagaimana produk distribusikan, dan apa saja kewajibannya?. Pemfokusan pada distribusi tidak berarti Islam tidak memperhatikan keuntungan yang diperoleh dari produksi. Islam memberikan gaji secara adil kepada para pegawai dan buruh jika mereka melaksanakan tugas dengan sempurna, sebagaimana Islam dengan tegas menolak segala bentuk riba. Distribusi ekonomi Islam berdiri di atas dua sendi, yaitu sendi kebebasan dan sendi keadilan.

Sendi pertama distribusi adalah kebebasan. Islam menetapkan kebebasan dalam kehidupan ekonomi manusia karena hakikat ekonomi dalam Islam kembali kepada dua hal, yaitu percaya kepada Allah dan percaya kepada manusia. Inti kepercayaan kepada Allah di dalam Islam adalah tauhid, yaitu ungkapan la ilaha illallah. Namun, tauhid tidak selesai dengan sekedar mengakui Allah sebagai satu-satunya sang pencipta. Hakikat tauhid adalah mengesakan Allah dalam beribadah dan memohon pertolongan. Islam datang membebaskan manusia dari penyembahan selain Tuhan Yang Maha Esa. Ia datang untuk menyampaikan misi bahwa semua manusia adalah sama. Semua saudara seperti anak-anak dalam satu keluarga (Yusuf Qardhawi, 203).

Oleh sebab itu, tidak seyogyanya manusia menyombongkan diri dan memeras sesama manusia. Adalah tidak wajar jika satu kelompok menganggap dirinya sebagai Tuhan yang pantas disembah oleh sebagian manusia yang lain. Islam menerapkan kebebasan karena ia menganjurkan kepada umatnya untuk percaya kepada Allah. Islam juga menetapkan kebebasan karena mengakui

\footnotetext{
al-Baqarah (2): 3 dan an-Nisa' (4): 39. Para mufasir berbeda penafsiran tentang maksud infak ini, apakah infak itu maksudnya zakat fardu, sedekah, atau menafkahkan harta untuk keluarga?. Para pemikir kontemporer condong mengatakan bahwa redaksi infak bertendensi seluruh bentuk infak, baik itu wajib ataupun sunat, untuk diri sendiri ataupun untuk keluarga, untuk masyarakat ataupun fi sabilillah (jalan Allah).
} 
eksistensi manusia, mengakui fitrah mereka untuk menyembah Allah. Islam mengakui kemuliaannya dan keahliannya. Karena itulah, kepada mereka Allah mengangkat manusia sebagai khalifah di muka bumi.

Sehubungan dengan asas kebebasan ini, kebebasan ekonomi yang disyariatkan Islam bukanlah kebebasan mutlak yang terlepas dari berbagai ikatan. Kebebasan tersebut adalah kebebasan yang terbatas, terkendali dan terikat dengan keadilan yang diwajibkan Allah. Meskipun terdapat perbedaan dalam perolehan rezeki sesuai dengan profesi dan keahlian, maka prinsip keadilan yang diserukan Islam mewajibkan mereka yang tidak mendapatkan pekerjaan akan ditelantarkan dan tertindas oleh golongan ekonomi kuat yang terlalu berambisi. Islam mewajibkan golongan ekonomi kuat agar mengulurkan tangan kepada kaum yang lemah (dhu'afa') agar mereka bisa berdikari.

Dengan demikian, sendi kedua distribusi adalah keadilan (keseimbangan). Ajaran Islam berorientasi pada terciptanya karakter manusia yang memiliki sikap dan prilaku yang seimbang dan adil dalam konteks hubungan antara manusia dengan diri sendiri, dengan orang lain (masyarakat) dan dengan lingkungan (Muslich, 2004: 37). Keseimbangan ini sangat ditekankan oleh Allah dengan menyebut umat Islam sebagai ummatan wasatan. Ummatan wasatan adalah umat yang memiliki kebersamaan, kedinamisan dalam gerak, arah dan tujuannya serta memiliki aturan-aturan kolektif yang berfungsi sebagai penengah atau pembenar. Dengan demikian keseimbangan, kebersamaan, kemoderenan merupakan prinsip etis mendasar yang harus diterapkan dalam aktivitas maupun entitas bisnis (Muhammad dan Lukman Fauroni, 2002: 13).

Agar keseimbangan ekonomi dapat terwujud maka harus terpenuhi tiga syarat. Pertama, produksi, konsumsi dan distribusi harus berhenti pada titik keseimbangan tertentu demi menghindari pemusatan kekuasaan ekonomi dan bisnis dalam genggaman segelintir orang. Kedua, setiap kebahagiaan individu harus mempunyai nilai yang sama dipandang dari sudut sosial, karena manusia adalah makhluk teo-morfis yang harus memenuhi ketentuan keseimbangan nilai yang sama antara nilai sosial marginal dan individual dalam masyarakat. Ketiga, tidak mengakui hak milik yang tak terbatas dan pasar bebas yang tak terkendali (Syed Nawab Naqvi, 1993: 99).

\section{Dimensi Kemanusiaan Dalam Bidang Sirkulasi}

Sirkulasi adalah pendayagunaan barang dan jasa lewat kegiatan jual beli dan simpan-pinjam melalui agen, koperasi, lembaga keuangan baik sebagai sarana perdagangan atau tukar-menukar barang (Yusuf Qardhawi, 171). Dimensi manusia dalam bidang sirkulasi menurut ekonomi Islam sangat fleksibel. Ia berbeda dengan ciri sosialis yang menolak kebebasan pasar dan tidak sama dengan sistem kapitalis yang menganut pasar bebas.

Dalam sistem kapitalis, pihak yang kuat memeras pihak yang lemah, yang cerdik menipu yang bodoh. Sementara, dalam Islam berpegang pada asas kebebasan dalam tatanan mu'amalah, termasuk dalam aktivitas pasar. Manusia 
bebas membeli, menjual, serta tukar-menukar barang dan jasa. Manusia menawar-kan dan menjual barang miliknya dan membeli barang kebutuhannya. Pada dasarnya Islam menganut prinsip kebebasan terikat, yaitu kebebasan berdasarkan keadilan.

Di dalam peraturan sirkulasi atau perdagangan Islami terdapat norma, etika agama, dan perikemanusiaan yang menjadi landasan pokok bagi pasar Islam yang bersih. Norma tersebut meliputi: pertama, manusia harus menegakkan larangan memperdagangkan barang-barang yang diharamkan. Kedua, manusia harus bersikap jujur, benar dan amanah dalam bertransaksi. Ketiga, manusia harus menegakkan keadilan dan menjauhi buga atau riba. Keempat, Manusia harus menerapkan kasih sayang dan mengharamkan monopoli. Kelima, manusia harus berpegang pada prinsip bahwa perdagangan adalah bekal menuju akhirat apabila menerapkan norma-norma tersebut (Lihat, an-Nisa' (4): 58, al-Jumu'ah (62): 9-11, dan al-Muthaffifin (83): 2-3).

\section{Penutup}

Islam sebagai agama yang Allah turunkan bukan saja untuk ummat Islam semata akan tetapi untuk seluruh ummat di dunia ini (rabmatan li al 'alamin) yang bersifat universal dan multikomplek. Islam dapat menjawab seluruh problematika dunia bukanlah hal utopis atau sesuatu yang ada dalam wacana saja, masalah ekonomi yang merupakan hajat hidup manusia juga tidak lepas dari ajaran Islam.

Dari uraian yang telah dipaparkan tersebut, paling tidak dapat ditarik dua hal pokok sebagai kesimpulan. Pertama, Islam pada dasarnya telah menyediakan suatu sistem ekonomi yang meniscayakan penggunaan sumber-sumber daya yang diberikan Allah untuk memenuhi kebutuhan-kebutuhan pokok umat manusia dan memberikan kepada mereka kondisi kehidupan yang baik. Kedua, sistem ekonomi Islam bukan hanya berlandaskan kepada nilai-nilai Ketuhanan dan moral, tetapi juga berdasarkan kepada prinsip kemanusiaan. Dimensi manusia sangat diperhatikan dalam rangka melakukan aktivitas ekonomi seperti produksi, konsumsi, distribusi dan sirkulasi.

\section{Daftar Pustaka}

Baqi' al-, Muhammad Fu'ad 'Abd, Al-Mu'jam al-Mufahras li Alfazal-Qur'an, Beirut: Dar al-Fikr, 1987.

Basyir, Ahmad Azhar, Garis Besar Sistem Ekonomi Islam, Yogyakarta: FE UGM, 1981.

Bukhari al-, Abu Abdillah Muhammad bin Isma'il bin Ibrahim bin Mugirah bin Bardizbah, Shabih Bukhari, Beirut: Dar Ibn Kasir, 1987.

Chapra, M. Umer, Sistem Moneter Islam, Jakarta: Gema Insani Press, 2000.

Ghazali al-, Abu Hamid, al-Mustasfa fi Tlm al-Usul, Beirut: Dar al-Kutub al'Ilmiyyah, 1983. 
Iswadi, Muhammad, "Ekonomi Islam: Kajian Konsep dan Pendekatan," Jurnal MAZAHIB Vol. IV, No. 1, Juni 2007.

Karim, Adiwarman Azwar, Sejarah Pemikiran Ekonomi Islam, Yogyakarta, Pustaka Pelajar, 2001.

Maraghi al-, Musthafa, Tafsir al-Maraghi, terj. Bahrun Abu Bakar dkk., Semarang: Toha Putra, 1993.

Muhamad, Metodologi Penelitian Pemikirian Ekonomi Islam, Yogyakarta: Ekonisia FE UII, 2004.

Muhammad dan Lukman Fauroni, Visi Alqur'an tentang Etika dan Bisnis, Jakarta: Salemba Diniyah, 2002.

Muslich, Etika Bisnis Islami; Landasan Filosofis, Normatif, dan Substansi-Implementatif, Yogyakarta : Ekonisia Fakultas Ekonomi UII. 2014

Naqvi, Syed Nawab, Etika dan Imu Ekonomi Suatu Sintesis Islami, terj. Husin Anis, Bandung: Mizan, 1993.

Qardhawi, Yusuf, Norma dan Etika Ekonomi Islam, Jakarta: Gema Insani Press, 1997.

Rahardjo, M. Dawan, Islam dan Transformasi Sosial Ekonomi, Jakarta: LSAF, 1999. Schumacher, F., Small is Beautiful, London: Blond and Briggs, 1973.

Shihab, M. Quraish, "Etika Bisnis dalam Wawasan Alqur'an,” Jurnal Ulumul Qur'an, No 3/VII/97.

Syatibi asy-, Abu Ishaq Ibrahim bin Muhammad, al-Munvafaqat fi Usul as-Syari'ah, Beirut: Dar Ibn 'Affan, 1997. 
